\title{
Prognosis for Pediatric Patients with Isolated Atrial Septal Defect
}

\author{
Deniz Özçeker, ${ }^{1}$ Pelin Ayyıldız, ${ }^{2}$ Metin Sungur, ${ }^{3}$ Mustafa Kemal Baysal ${ }^{4}$
}

\section{'Department of Pediatric Allergy, İstanbul University Faculty of Medicine, Istanbul, Turkey ${ }^{2}$ Department of Pediatric Cardiology, Mehmet Akif Ersoy Thoracic and Cardiovascular Surgery Training and Research Hospital, Istanbul, Turkey \\ 3Department of Pediatric Cardiology, Kartal Koşuyolu Training and Research Hospital, Istanbul, Turkey ${ }^{4}$ Department of Pediatric Cardiology, Ondokuz Mayıs University Faculty of Medicine, Samsun, Turkey \\ Submitted: 23.06.2015 Accepted: 20.08.2015}

Correspondence: Deniz Özçeker Istanbul Üniversitesi Tıp Fakültesi, Çocuk Alerji Kliniği, Fatih, İstanbul, Turkey

E-mail: denizozceker@gmail.com

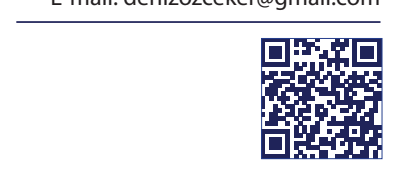

Keywords: Atrial septal defect; child; prognosis.

\begin{abstract}
Objective: Atrial septal defect (ASD) is the second most frequently seen type of congenital heart disease. The aim of the present study was to predict clinical prognosis of ASD based on age at diagnosis, patient complaints, findings of physical examination, electrocardiogram and telecardiogram results, and echocardiographic measurement of diameter of defect in 388 patients with ASD.
\end{abstract}

Methods: Patients at pediatric cardiology outpatient clinic of Ondokuz Mayıs University Faculty of Medicine Department of Children's Health and Diseases between January 2003 and June 2008 who were $0-18$ years of age, had echocardiographic examinations performed at least twice, and were followed-up for at least 6 months were included in the study.

Results: The study population included 182 (46.9\%) male and 206 (53.1\%) female patients (female/male ratio: I.I3) with median age at diagnosis of 3 months (range: I month-17 years). In 189 patients (53.4\%), ASD closed spontaneously. A total of 24 patients $(6.8 \%$ ) underwent surgery. In 43 patients ( $12.1 \%$ ), defect was repaired using transcatheter procedure. At time of study, 98 patients (27.7\%) were still under follow-up care. Early diagnosis and diameter of defect correlated with spontaneous closure $(p<0.001)$.

Conclusion: Age at diagnosis and size of defect are the most important criteria for clinical prognosis and spontaneous closure of defect in cases of ostium secundum ASD.

\section{INTRODUCTION}

All holes in the atrial septum apart from foramen ovale are defined as atrial septal defect (ASD). ${ }^{[1,2]}$ Although incidence rate of ASD in children varies among authors, it constitutes some $6 \%$ to $10 \%$ of all congenital cardiac

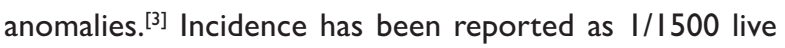
births. ${ }^{[4]}$ However in novel studies performed using colorDoppler echocardiography, much higher incidence rates $(0.2 \%)$ have been reported. ${ }^{[5]}$ Infants are now sent to pediatric cardiology centers at an earlier age, which lowered mean detection age of ASD, and patients have been reported to be diagnosed at median age of 6 months. ${ }^{[2]}$ In the absence of any concomitant cardiac defect, and if the defect is not too large, prognosis is quite good. ASDs reportedly close spontaneously in 14\% to $66 \%$ of infant cases. ${ }^{[6]}$

In the present study, we sought to investigate prognosis of ASD cases followed-up at the clinic.

\section{MATERIAL AND METHODS}

Medical files of 354 patients below age of 182008 who 
were diagnosed with isolated ASD at Ondokuz Mayıs University Faculty of Medicine Department of Pediatric Cardiology clinic between January 2003 and June 2008, and who followed-up with echocardiographic diagnosis were retrospectively analyzed. Approval for this study was obtained from the institution. Study group consisted of patients who were followed-up for 6 months or longer and who underwent echocardiographic examinations at least twice.

Diagnosis, age, body weight, admission complaints, physical examination results, electrocardiographic (ECG) and telecardiographic findings, echocardiographic measurements of defect diameter, and clinical outcomes were recorded on prepared patient information form. Echocardiographically measured defect diameters were grouped by size: small (3-5 mm), medium (6-8 $\mathrm{mm})$, and large ( $\geq 9$ $\mathrm{mm}$ ). Cases were divided into 3 groups based on patient age at diagnosis as follows: I-24 months, 25-60 months, and $\geq 6$ I months. In addition, patients were categorized into 4 groups according to follow-up results as patients whose defect closed spontaneously, was repaired using surgical or transcatheter methods, and those still under observation.

Closure of ASD should be confirmed with echocardiographic examination. Lack of cardiac murmur on auscultation during physical examination was not accepted as sole criterion for defect closure.

\section{Statistical evaluation}

After coding research findings, statistical analysis was conducted using SPSS software (version 15.0; SPSS Inc., Chicago, IL, USA). Normality tests were performed for all measurable variables. Scores were compared using non-parametric Mann-Whitney $U$ test and Wilcoxon test. Other measurable variables with normal distribution were subjected to intragroup and intergroup comparisons before and after procedures using independent samples t-test and paired samples t-test, respectively. For variables with non-normal distribution, inter- and intragroup comparisons were performed using Mann-Whitney $U$ test and Wilcoxon test. Pre- and postprocedure comparisons of categorical variables expressed as frequencies were performed using likelihood ratio test for 2 samples, Fisher's exact test, and McNemar's test. For parametric tests, measurements were expressed as mean $\pm S D$, and for nonparametric tests as median, minimum, and maximum. Correlations between some parameters were determined using logistic regression analysis. $\mathrm{P}<0.05$ was accepted as the level of statistical significance.

\section{RESULTS}

A total of 354 patients (female: $n=192,54.2 \%$; male: $n=I 62,45.8 \%$; F/M ratio: I.I8 ) with a diagnosis of isolated ASD at median age of 3 months (min. I month, max. 204 months) who attended regular follow-up visits were included in the study. Patients were diagnosed in the following age ranges: I-24 months $(n=276 ; 78 \%)$, 25-60 months ( $n=19 ; 5.4 \%)$, and $\geq 61$ month-old. The most frequent reason for admission was auscultation of murmur (87.3\%). In all age groups, first-degree murmur $(62.4 \%)$ was the most frequently detected cardiac examination finding. In 44 cases (12.4\%), split second heart sounds were heard. In 43 patients (I2.1\%), cardiomegaly was detected on telecardiogram. In 18 (41.9\%) cases with cardiomegaly, defect diameter was $\geq 9 \mathrm{~mm}$. In $72.3 \%$ of cases, ECG findings were evaluated as normal. The most frequently detected ECG abnormality was right ventricular overload, recorded in 62 (17.5\%) patients. Diameter of ASD as measured on ECG was 3-5 mm in $58.2 \%$ $(n=226), 6-8 \mathrm{~mm}$ in $22.4 \%$, and $\geq 9 \mathrm{~mm}$ in $19.3 \%$ of patients, respectively. Defect diameter was $3-5 \mathrm{~mm}$ in 189 patients $(68.5 \%)$ whose age at diagnosis was between I and 24 months, while it was $\geq 9 \mathrm{~mm}$ in $36(61 \%)$ patients who were diagnosed when they were $\geq 6$ I months old. ASD closed spontaneously $(n=189 ; 53.4 \%)$, was repaired surgically $(n=24 ; 6.8 \%)$, or using transcatheter method $(n=43 ; 12.1 \%)$. At time of study, 98 (27.7\%) patients were still receiving follow-up care. Spontaneous defect closure rates are provided in Table $\mathrm{I}$.

Median age of patients at time of diagnosis according to clinical follow-up results is shown in Table 2 .

In only 6 of the 67 cases of ASD with diameter of $\geq 9$ $\mathrm{mm}$ was spontaneous defect closure observed. The remaining 61 cases required surgery $(n=19 ; 28.4 \%)$, or use of transcatheter occlusion method $(n=34 ; 50.7 \%)$ to close the defect. No patient in the group $(n=213)$ with defect diameter between 3 and $5 \mathrm{~mm}$ required closure procedure, and defects of 152 (7I.4\%) patients in this group closed spontaneously. Spontaneous closure also occurred in 31 patients (4I.9\%) with defect diameter of 6-8 mm, and 6 patients $(9 \%)$ with defect diameter of $\geq 9 \mathrm{~mm}$. A statistically significant intergroup difference was discovered regarding defect diameter and spontaneous closure of defect $(p<0.001)$.

Mean age at spontaneous closure was 25.36 \pm 2.15 months. A correlation was found between spontaneous closure, age at diagnosis, and echocardiographically measured ASD diameter. 
Table I. Rates of spontaneous closure of atrial septal defect based on age of diagnosis

\begin{tabular}{|c|c|c|c|c|c|c|}
\hline \multirow[t]{2}{*}{ Age at diagnosis } & \multicolumn{2}{|c|}{ Lack of spontaneous closure } & \multicolumn{2}{|c|}{ Spontaneous closure } & \multicolumn{2}{|c|}{ Total } \\
\hline & $\mathbf{n}$ & $\%$ & $\mathbf{n}$ & $\%$ & $\mathbf{n}$ & $\%$ \\
\hline I-24 months & 125 & $4 I .1$ & 179 & 58.9 & 304 & 100 \\
\hline $25-60$ months & 16 & 66.7 & 8 & 33.3 & 24 & 100 \\
\hline$\geq 61$ months & 58 & 96.7 & 2 & 3.3 & 60 & 100 \\
\hline
\end{tabular}

$p<0.001$

Table 2. Distribution of mean age at diagnosis according to follow-up results

\begin{tabular}{lcc}
\hline Result of clinical follow-up & Mean $\pm S D$ (months) & Min.-Max. (months) \\
\hline Spontaneously closed ASD & $6.14 \pm 1.01$ & $1-108$ \\
ASD closed using transcatheter & $93.76 \pm 10.35$ & $1-204$ \\
ASD closed using surgery & $70.25 \pm 11.70$ & $1-186$ \\
Patients still in follow-up & $24.28 \pm 4.28$ & $1-168$ \\
Patients lost to follow-up & $16.08 \pm 4.11$ & $1-108$ \\
Total & $25.32 \pm 45.15$ & $1-204$ \\
\hline
\end{tabular}

SD: Standard deviation; ASD: Atrial septal defect.

Factors affecting spontaneous closure of ASD are shown in Table 4.

Factors indicating surgical closure of ASD are shown in Table 5.

Factors requiring use of transcatheter method to close ASD are shown in Table 6.

Of the patients still under observation $(n=6 I)$ whose defect diameter ranged between 3 and $5 \mathrm{~mm}$, no change in size was seen during the follow-up period. In 17 of 29 cases with defect diameter between 6 and $8 \mathrm{~mm}$, regression to 3-5 $\mathrm{mm}$ was observed, while in 3 cases diameter increased to $9 \mathrm{~mm}$ or more. In 2 of 8 cases with baseline defect diameter of $\geq 9 \mathrm{~mm}$, defect diameter did not change, while in the remaining 6 cases defect diameters decreased.

\section{DISCUSSION}

ASD is one of the most frequently detected congenital heart diseases. Infants are now sent to centers of pediatric cardiology at an earlier age, which has lowered mean detection age for ASD to 6 months. ${ }^{[2]}$

In the present study, female/male ratio was I.I3. Twofold increase in the incidence of ASD has been reported in female children and adults compared to their male counter- parts. ${ }^{[3,7]}$ However, in the current study, despite greater number of female cases of ASD, a marked difference was not detected. Diagnosis of ASD was most often made between I and 24 months of age. However, while $88.5 \%$ of the cases with small defect diameter $(3-5 \mathrm{~mm})$ were diagnosed before 2 years of age, only $10 \%$ of patients with defect diameter of $\geq 9 \mathrm{~mm}$ were also diagnosed between I and 24 months of age. Nearly half (49.3\%) of cases with defect diameter of $\geq 9 \mathrm{~mm}$ were diagnosed when they were $\geq 6 \mathrm{I}$ month old. In the present study, it was found that age at diagnosis increased in line with defect diameter. Similarly, Ertürk et al. found median age of 2 months for diagnosis of ASD of less than $4 \mathrm{~mm}$ in diameter, while it was 26 months of age for ASD greater than $8 \mathrm{~mm}$ in diameter. ${ }^{[8]}$ Asymptomatic clinical progression of ASD is

Table 3. Diameter of atrial septal defect according to age at diagnosis

\begin{tabular}{cccc}
\hline & $\begin{array}{c}\text { I-24 } \\
\text { months } \\
(\mathbf{n})\end{array}$ & $\begin{array}{c}25-60 \\
\text { months } \\
(\mathbf{n})\end{array}$ & $\begin{array}{c}\geq 6 \text { I } \\
\text { months } \\
(\mathbf{n})\end{array}$ \\
\hline $3-5 \mathrm{~mm}$ & 189 & 10 & 14 \\
$6-8 \mathrm{~mm}$ & 61 & 4 & 9 \\
$>9 \mathrm{~mm}$ & 26 & 5 & 36 \\
\hline
\end{tabular}


Table 4. Evaluation of factors affecting spontaneous closure of atrial septal defect

\begin{tabular}{lccc}
\hline & OR (Odds Ratio) & p & $\begin{array}{c}\text { Confidence } \\
\text { interval }\end{array}$ \\
\hline Age at diagnosis & 1.398 & 0.001 & $1.174-1.666$ \\
Echocardiographic measurement of defect diameter & 1.032 & 0.001 & $1.016-1.048$ \\
\hline
\end{tabular}

Table 5. Evaluation of factors requiring surgical closure of atrial septal defect

\begin{tabular}{lccc}
\hline & OR (Odds Ratio) & p & $\begin{array}{c}\text { Confidence } \\
\text { interval }\end{array}$ \\
\hline Electrocardiography & 0.539 & 0.313 & $0.162-1.790$ \\
Telecardiography (Cardiomegaly) & 0.627 & 0.434 & $0.195-2.017$ \\
Age at diagnosis & 1.005 & 0.344 & $0.994-1.017$ \\
Echocardiographic measurement of defect diameter on & 0.718 & 0.001 & $0.624-0.827$ \\
\hline
\end{tabular}

Table 6. Evaluation of factors requiring transcatheter closure of atrial septal defect

\begin{tabular}{lccc}
\hline & OR (Odds Ratio) & p & $\begin{array}{c}\text { Confidence } \\
\text { interval }\end{array}$ \\
\hline Electrocardiography & 0.366 & 0.021 & $0.156-0857$ \\
Telecardiography (Cardiomegaly) & 1.658 & 0.406 & $0.504-5.455$ \\
Age at diagnosis & 0.981 & 0.001 & $0.974-0.988$ \\
Echocardiographic measurement of defect diameter & 0.947 & 0.198 & $0.872-1.029$ \\
\hline
\end{tabular}

important and may be related to spontaneous closure of small defects at an early age.

On physical examination of patients with ASD, systolic murmur over pulmonary focus and fixed splitting of second heart sound were frequently heard. In the present study, the most frequent reason for admission was auscultation of murmur (87.3\%). Similarly, Demir et al. also reported auscultation of murmur as primary admission complaint. ${ }^{[9]}$

In $73 \%$ of cases with defect diameter of $\geq 9 \mathrm{~mm}$, ECG demonstrated right ventricular overload and right bundle branch block. Christensen et al. evaluated 47 patients whose median defect diameter was $13 \mathrm{~mm}$ and detected normal ECG findings in only $18 \%$ of cases. ${ }^{[10]}$ Azhari et al. detected right ventricular conduction delay in $88 \%$ of 121 patients, and demonstrated increases in right ventricular and atrial load on ECG in parallel with increase in defect diameter. ${ }^{[I]}$ Outcomes of present study were similar to those in the literature.
In the current study, ASD spontaneously closed in $48.5 \%$ of cases. Defects with diameter of 3-5 mm, 6-8 mm, and $\geq 9 \mathrm{~mm}$ spontaneously closed in $67 \%, 35 \%$, and $8 \%$ of cases, respectively. Ertürk et al. and Fukazawa et al. separately detected spontaneous closure rates of $57 \%$ and $66 \%$, respectively. ${ }^{[8,12]}$ Hanslik et al. found incidence of spontaneous closure of $34 \%$ and in $56 \%$ of cases with defects of diameter between $4 \mathrm{~mm}$ and $5 \mathrm{~mm} \cdot{ }^{[13]} \mathrm{In}$ a study by Radzik et al., spontaneous closure rates were reported as $87 \%$ and $80 \%$ in ASD with diameter of $3-5 \mathrm{~mm}$ and $6-8$ $\mathrm{mm}$, respectively. ${ }^{\left[{ }^{[4]}\right.}$ Helgason et al. evaluated spontaneous closures in 84 cases and detected spontaneous closure of defects in $89 \%, 79 \%$, and $7 \%$ of patients whose ASD was of 4, 5-6 mm, and $\geq 6 \mathrm{~mm}$ in diameter, respectively. ${ }^{[15]}$ Ertürk et al. reported spontaneous closure rate of $>90 \%$ in ASDs with diameter of less than $4 \mathrm{~mm}$, and only $8 \%$ in cases with defect diameter of more than $8 \mathrm{~mm} .{ }^{[8]}$ Present study results were in compliance with those of the literature. We attribute diverse outcomes about spontaneous 
closure rates of ASD to evaluation of patient groups of different age groups and defect diameter.

In the present study, spontaneous closure of ASD was observed in $58.9 \%$ of patients diagnosed between I month and 24 months of age and in $33.3 \%$ of patients whose ASD was diagnosed when they were 25-60 months of age. In only $3.3 \%$ of patients older than 61 months was spontaneous closure noted. A statistically significant difference was found among the 3 groups regarding spontaneous closure. Mody reported higher incidence of spontaneous closure in patients diagnosed when they were 12 months old or younger. Hanslik et al. reported spontaneous closure of ASDs in $39 \%$ and $19 \%$ of patients younger and older than 12 months of age, respectively. ${ }^{[12,16]}$ Cockerham et al. reported spontaneous closure rates of $22 \%, 33 \%$, and $3 \%$ in patients younger than 12 months old, I-2 years old, and 2-4 years old, respectively. ${ }^{[17]}$ Present results were in agreement with those of the literature.

Spontaneous closure of ASD reportedly occurs between 2 and 8 years of age, however mechanism of closure is not completely understood. ${ }^{[2]}$ In the present study, mean age at spontaneous closure was 25.36 \pm 20.15 months. Similarly, in a study by Azhari et al., $94 \%$ of spontaneously closed ASDs occurred when patient was younger than 2 years of age. However, Hüdaoğlu detected significantly higher spontaneous closure rates in patients younger than 22 months of age. ${ }^{[1,18]}$ As cited in the literature, the oldest patient with spontaneous closure of ASD was 16 years old. ${ }^{\left[{ }^{19]}\right.}$ In our study, the oldest patient whose defect closed spontaneously was 10 -and-a-half years old.

In the present study, $25 \%$ of the 75 cases with defect diameter equal to or greater than $9 \mathrm{~mm}$ were closed using surgical means, and transcatheter occlusion method was employed for $45 \%$ of these cases. Hanslik et al. reported that $77 \%$ of defects of $\geq 10 \mathrm{~mm}$ in diameter were closed using surgery or transcatheter occlusion method. ${ }^{[13]}$ In a study by Ertürk et al, $90 \%$ of defects with diameter of $8 \mathrm{~mm}$ or more required surgical closure methods. ${ }^{[8]}$ In a study by Christensen et al., authors used surgical methods to close defect in $60 \%$ of patients. ${ }^{[10]}$ Availability of transcatheter method for closure of ASD at our center may explain lower surgical closure rate in present study relative to the literature findings.

In conclusion, in cases of secundum-type ASD, patient age and size of defect at diagnosis are the most important factors with regard to spontaneous closure and prognosis. After evaluation of all the outcomes, it can said that if the diameter of the defect is between $3 \mathrm{~cm}$ and $5 \mathrm{~cm}$, most often spontaneous closure will occur; however, if the defect is $9 \mathrm{~mm}$ or larger then surgical or transcatheter methods can achieve closure in $70 \%$ of cases. Similarly, spontaneous closure was observed in $60 \%$ of patients whose age at diagnosis was less than 24 months; however, spontaneous closure was seen in only $3 \%$ of those whose age at diagnosis was greater than 5 years. That is, ASD of $90 \%$ of patients whose age at diagnosis and diameter of defect are relatively small will likely close spontaneously. It is the opinion of the authors that it would be appropriate to follow-up these cases at 6 to 12 month intervals.

\section{REFERENCES}

1. Fyler DC. Atrial septal defect secundum. In: Keane JF, editor. Nadas Fyler DC. Pediatric cardiology. 3rd ed., Philadelphia: W.B. Saunders; 1972. p. 513-24.

2. Allen HD, Driscoll DJ, Shaddy RE, Feltes TF. Atrial septal defects. In: Allen HD, editor. Moss and Adam's Heart Disease in infants, children and adolescent: Including the fetus and young adults. 7th ed., 2008, p. 632-44.

3. Campbell M. Natural history of atrial septal defect. Br Heart J 1970;32:820-6.

4. Glenn WWL. Thoracic and cardiovascular surgery. 4th ed., Norwalk-Connecticut: Appleton-Centory-Crofte; 1983.

5. Garne E. Atrial and ventricular septal defects - epidemiology and spontaneous closure. J Matern Fetal Neonatal Med 2006;19:271-6.

6. Gross RE, Pomeranz AA, Watkıns E JR, Goldsmıth EI. Surgical closure of defects of the interauricular septum by use of an atrial well. N Engl J Med 1952;247:455-60.

7. Bozer AY. Kalp hastalıkları ve cerrahisi. 1985.

8. Ertürk L, Özyürek AR, Ülger Z, Güven H, Parlar A. Spontaneous closure of secundum-type atrial septal defects. SSK Tepecik Hast Derg 2002;12:97-100.

9. Demir T, Oztunç F, Eroğlu AG, Saltik L, Ahunbay G, Kutluğ S, et al. Outcome for patients with isolated atrial septal defects in the oval fossa diagnosed in infancy. Cardiol Young 2008;18:75-8.

10. Christensen DD, Vincent RN, Campbell RM. Presentation of atrial septal defect in the pediatric population. Pediatr Cardiol 2005;26:812-4.

11. Azhari N, Shihata MS, Al-Fatani A. Spontaneous closure of atrial septal defects within the oval fossa. Cardiol Young 2004;14:148-55.

12. Fukazawa M, Fukushige J, Ueda K. Atrial septal defects in neonates with reference to spontaneous closure. Am Heart J 1988;116:123-7.

13. Hanslik A, Pospisil U, Salzer-Muhar U, Greber-Platzer S, Male C. Predictors of spontaneous closure of isolated secundum atrial septal defect in children: a longitudinal study. Pediatrics 2006;118:15605.

14. Radzik D, Davignon A, van Doesburg N, Fournier A, Marchand T, Ducharme G. Predictive factors for spontaneous closure of atrial septal defects diagnosed in the first 3 months of life. J Am Coll Cardiol 1993;22:851-3.

15. Helgason H, Jonsdottir G. Spontaneous closure of atrial septal defects. Pediatr Cardiol 1999;20:195-9.

16. Mody MR. Serial hemodynamic observations in secundum atrial septal defect with special reference to spontaneous closure. Am J Cardiol 1973;32:978-81. 
17. Cockerham JT, Martin TC, Gutierrez FR, Hartmann AF Jr, Goldring D, Strauss AW. Spontaneous closure of secundum atrial septal defect in infants and young children. Am J Cardiol 1983;52:126771.

18. İzole atriyal septal defekt, ventriküler septal defekt ve patent duktus arteriozus'un klinik seyri. Dr. Suphi Hüdaoğlu. Dokuz Eylül Üniversitesi Tıp Fakültesi çocuk sağlığı ve hastalıkları uzmanlık tezi. 1998.

19. Hagen PT, Scholz DG, Edwards WD. Incidence and size of patent foramen ovale during the first 10 decades of life: an autopsy study of 965 normal hearts. Mayo Clin Proc 1984;59:17-20.

\section{İzole Atriyal Septal Defektli Hastalarda Klinik Seyir ve Prognoz}

Amaç: Atriyal septal defekt (ASD) çocuklarda ikinci sıklıkta görülen doğumsal kalp hastalığıdır. Bu çalışmada, kliniğimizde ASD tanısı alan 354 olgunun tanı yaşı, başvuru yakınmaları, fizik muayene, elektrokardiyografi ve telekardiyografi bulguları ve ekokardiyografik olarak ölçülen defekt çapı kullanılarak ASD'nin klinik seyri ve prognozu hakkında tahminde bulunabilmek amaçlandı.

Gereç ve Yöntem: Çalışma grubumuz, Ocak 2003 ile Haziran 2008 tarihleri arasında Ondokuz Mayıs Üniversitesi Tıp Fakültesi Çocuk Kardiyoloji Polikliniği'ne başvuran, 0-I8 yaş grubunda, en az altı ay ve üzerinde izlem süresi ve en az iki defa ekokardiyografi yapılan olgulardan oluşmaktadır.

Bulgular: Olguların 206'sı (\%53.I) kız, I82'si (\%46.9) erkekti, Kız/Erkek: I.I3 olarak bulundu. Olguların ortanca tanı yaşı üç ay (I/I2-I7 yaş) olarak bulundu. Atriyal septal defekti kendiliğinden kapanan hasta sayısı 189 (\%53.4), ameliyat edilen hasta sayısı 24 (\%6.8), transkateter yöntem ile defekti kapatılan hasta sayısı 43 (\%।2.I) ve izlemi devam eden hasta sayısı 98 (\%27.7) olarak bulundu. Defekti kendiliğinden kapanan olgular incelendiğinde kendiliğinden kapanma ile olguların tanı yaşları ve ölçülen ekokardiyografi çapları arasında anlamlı ilişki olduğu görüldü $(\mathrm{p}<0.00 \mathrm{I})$.

Sonuç: Sekundum tip ASD'lerde tanı yaşı ve tanı anındaki defektin büyüklüğü kendiliğinden kapanma ve prognozda en önemli faktörlerden birisidir.

Anahtar Sözcükler: Atriyal septal defekt; çocuk; prognoz. 